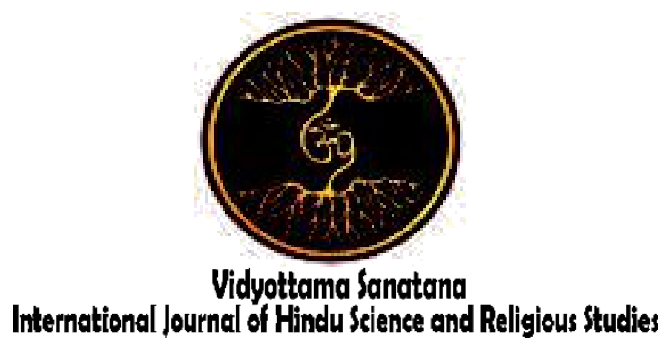

Vol. 2 No. 2 October 2018

\title{
Internalization Values Of Character Education Towards The Teruna-Daha In The Medi-Median Tradition
}

\author{
By: \\ Akio Hiroyuki ${ }^{1}$, I Nengah Juliawan ${ }^{2}$, I Ketut Sudarsana ${ }^{3}$ \\ ${ }^{1}$ Japan Institute of Balinese Studies \\ ${ }^{23}$ Institut Hindu Dharma Negeri Denpasar \\ E-mail : ${ }^{3}$ iketutsudarsana@ihdn.ac.id
}

Received: August 3, 2018

Accepted: September 4, 2018

Published: October 31, 2018

\begin{abstract}
National culture and character education is a concept of character education in Indonesia, namely through the process of internalization of education based on the principles of religious, social and cultural norms. The medi-median tradition is one of the cleansing ceremonies that returns all elements in Bhuana Agung and Bhuana alit back to its place, which is carried out by Krama desa in the traditional village of Tenganan Pegringsingan, which in this tradition gives deep meaning as an internalization of values that form the character of religious young people. General objectives and specific objectives to examine and analyze medi-median traditions, related to the internalization of the value of character education. This type of qualitative research used religious theory, internalization theory, value theory, and ethnographic research approaches. Accumulation data used observation method, interview method, library method, data that has been collected is analyzed by interpretative descriptive analysis method, analysis conducted during and after accumulation data, data reduction activities, data presentation, verification to make conclusions. The results presentation technique is presented by the method of presenting the data formally and informally. Research results (1) The medi-median tradition is carried out at Sasih Kapitu, with a series of muhu-muhu ceremonies in the dalem kangin and medi-median in the north to south of the village area, with implementation plans initiated by the medimedian initiator. (2) Internalization of character values through 3 stages, namely the value transformation stage, transaction value stage and transinternalisation stage. (3) internalization of character values towards the teruna-daha in the medi-median tradition, which are: religious values, social values, values. tolerance, discipline value, friendly/communicative value, creative value, aesthetic value, and value of responsibility.
\end{abstract}

Keywords: Medi-median tradition, character education, internalization of values, Teruna-daha 


\section{Introduction}

Human individuals always process to shape their character, where a character is formed that starts from family, school, and environment. Formally the formation of human character is formed consciously and systematically in developing self potential called education carried out in school institutions. The process or way of instilling normative values that determine the desired behavior for a system that educates in accordance with the guidance towards the formation of a dignified and characterized national personality, namely through the process of internalization of education based on the principles of religious, social and cultural norms. Internalization is the inside or inside, about appreciation of a teaching or value, so that the belief and awareness of the truth about values are manifested in attitudes and behavior.

The decline in moral quality that has occurred in Indonesian human life today, especially among students has been at a very alarming level. Moral decadence in the young generation is a reflection of the character's crisis so that it requires a shared commitment in shaping the character of our current generation. Every activity, regardless of form and type, is conscious or unconscious is always expected to the goal to be achieved. Education as a form of human activity in his life also places the goal as something to be achieved, both the objectives formulated are abstract to formulations specifically formed to facilitate higher achievement. The noble goals of education in Indonesia as stated in the laws and regulations do not seem to be in line with the reality on the ground. The gap between national education expectations and the reality that occurs is the rise of teens delinquency cases ranging from student brawls, free sex to homicides between students. Cases that are rife in the world of education due to lack of moral understanding.

This requires educational institutions and teaching staff to evaluate and reflect on educational methods and curricula that have been the reference in the teaching and learning process. According to Professor of Educational Psychology Prof.Emiritus Conny R.Semiawan, in the midst of pluralism in Indonesian society there is always a trade off between equal educational opportunities and equal educational outcomes.

Regarding cultural and religious issues, Balinese people have diverse traditions. In every region in Bali, it has a peculiarity about different traditional activities in the conduct of religious ceremonies. " Every place has a ceremony procedure that is carried out in accordance with the local workshop (desa kala patra and desa mawacara).

Similar to other villages in Bali, in the Tenganan pegringsingan traditional Village also has ceremonies similar to Balinese in general, namely the Tawur or Pengrupukan ceremonies, but there is a deep difference in terms of time, procedure, culture and aesthetics. in the ceremony procession or better known among the people of the Tenganan Pegringsingan Indigenous village with the Medi-median name. Tenganan pegringsingan traditional village as a representative of the Bali Aga people who still adhere to traditional customs seems to have succeeded in proving that they still exist despite being surrounded by globalization and the development of information technology, in the fields of Religion, social, law and even education, the Tenganan Pegringsingan community still entrusts the tradition local as a form of humanistic education. Traditions that are based on customs in the Tenganan Pegringsingan traditional village that are so interesting to talk about and take a closer look, one of which is the Medi-median tradition as a place of implication about the internalization values of character that are devoted to the people in the Tenganan Pegringsingan village.

The Medi-median tradition is one of the cleansing and restoring ceremonies, all elements in Bhuana Agung and Bhuana Alit are back in their place, which is carried out 
by Krama desa in the traditional village of Tenganan Pegringsingan, where in this tradition it provides deep meaning as an internalization of values that shape the character of the Hindu community religious. This tradition is very unique because the traditional village of Tenganan Pegrinngsingan from the time of its ancestors has considered the meaning of life, how everything should be maintained and developed and returned to its place by upholding gratitude for what has been received by the creator, by looking at it. there is an internalization of character values given through a Medi-median ceremony process that aims to form strong character and the determination and morale of the community of Tenganan Pegringsingan Traditional Village.

\section{Method}

Methods are strategic ways to understand realist, systematic steps to solve the causal sequence. Methodology also means how to do things by using the mind carefully to achieve a goal. According Sugiyono (2009: 193) accumulation data techniques are a method specifically used to find or obtain data, record events or things, information or characteristics of some or all elements of the population, with the right data collection method will later It is expected that this research will be useful for all elements of society. 1). Observation method is an observation to observe the actions or behavior of objects made or used by the community by observing directly or indirectly about the things observed and recording them. 2). The interview method is a research technique carried out by means of dialogue both directly (face to face) and indirectly (using the media, between the interviewer and the interviewee as the data source. 3). The literature method is a accumulation data technique that is carried out by collecting various written data sources that support the research. Data analysis is a series of activities to review, classify, systematize, interpret and verify data so that a phenomenon has academic and scientific social value.

\section{Results and Disscusion}

Tradition is the spirit of a culture, with the cultural system tradition will become strong. If tradition is eliminated then there is hope that a culture will end right away. The implementation of the teachings of Hinduism in Bali is integrated with many local traditions inherited from generation to generation. One of them is found in the traditional village of Tenganan Pegringsingan namely "Medi-median Tradition" which is carried out as part of the Muhu-muhu ritual ceremony held at Sasih Kapitu Hud pang solas, adjusted to the calendar in the Tenganan Pegringsingan Traditional Village.

In connection with a tradition of mutual respect between the lives of living things both on a scale and a non-life basis, the ritual/religious clad tradition has a function of balancing life, as well as the medi-median tradition carried out by the Tenganan Pegringsingan traditional village community that prioritizes a balance of life, which aims to harmonize Bhuana Agung and Bhuana Alit to realize happiness and happiness born inward (jagadhita and moksa), the development of life based on satyam (truth), siwam (holiness), and sundaram (harmony/beauty).

Masanggah jummu is the beginning of a medi-median series of traditions which is held when in Sasih kenam hud pang solas (11), masanggah jummu which has a word meaning that the place of honor performed at the beginning of sasih kaenam, Masanggah Tengah is a series before the muhu-muhu ceremony was held, towards the medimedian tradition, masanggah is being carried out after 15 days from masanggah jummu, if it is associated in the dating system in the traditional village of tenganan pegrinngsingan namely precisely date of when in kajengkliwon sasih kapitu tanggal pang solas (11).

Sasih kapitu hud pang solas that right when kajengkliwon is the initial process of 
the medi-median tradition, Krama desa adat tenganan pegringsingan male and female in the morning performing a ritual offering by carrying out Masanggah Duri. Masanggah Duri is the final process of masanggah which is carried out by the village, the same as with the masanggah jummu and masanggah tengah. The morning after the masanggah duri ceremony was completed, krama desa of the Tenganan Pegringsingan traditional village held a ceremony, to finalize the activities to be carried out. Sangkepan in Bale Agung is only followed by the krama desa muani, by dividing themselves into 2 parts in accordance with the applicable rules at the village organization level. The part that sits on the right will be given the task of completing the ceremony in dalem kangin or in the emissary and the part that sits to the west remains in Bale Agung to carry out of medi-median tradition preparations.

The medi-median tradition began to be carried out from the northern place in front of the pura sri of the traditional village of Tenganan Pegringsingan or what is referred to as the lawangan desa kaja (the north entrance to the village), which was lead by Tampingtakon 2 accompanied by the krama desa luh, to begin the muhu-muhu ceremony, nedehang (herding) memedi (niskala creatures), starting from the north to the south, according to the concept of Jaga Satru. The medi-median created in the Medimedian tradition is the embodiment of Bhuta Kala which is the realization of a large and creepy creature, but in medi-median terms symbolically in the traditional village of tenganan pegringsingan are made to a size that suits your needs, not like ogoh-ogoh in general.

The start of Tampintakon 2 thrusts the blast in each passageway at that same time as well as kul-kul of traditional village Tenganan Pegringsingan is sounded by the teruna and the culverts in each house and bale patemu are also sounded the same way, this indicates that the medi-median tradition has begun and Lemeh Village or village is in a state of gloom. The medi-median tradition whose process begins when the jejeg matan $a i$ is (at noon) at the same time, the village man who sits to the east called ngecana who is in charge of di dalem kangin or pengemitan performs the process of muhumuhu, if categorized as the medi-median that takes place in the northern village area goes south is a form of the process of balance between pawongan (human) and palemahan (natural) and for those in charge in dalem kangin leads more towards parahyangan (God).

The ceremony of muhu-muhu in its implementation by the krama desa muani (Ngecana) uses the yadnya in the form of godel bulu miik (calf), which has meaning as a form of sincerity and sanctity of an offering to prostrate bhakti to Ida who is in dalem kangin, according to belief Krama desa traditional Tenganan Pegringsingan. The godel bulu miik feathers are also a means intended by Krama desa as a form of debt redemption, or the redemption of errors in village defilements carried out by the krama desa by causing the village area as well as individuals in Tenganan Pegringsingan to be Leteh or cuntaka. Godel Bulu Miik is a mandatory upakara in the muhu-muhu procession.

The Medi-median tradition in the process is planned by the initiator, where the initiator in this tradition is Kelihan Desa of traditional village tenganan pegringsingan as the highest leader in village who decides or gives directions on planning to be carried out in carrying out the medi-median tradition. The structural organization in the Tenganan Pegringsingan Traditional Village has a standard rule, which has been stated in the Awig-awig (Law) of the village, namely all village equipment from Luanan to Krama desa, determined by the level of marriage, who is married first (married to fellow people from Desa Adat Tenganan Pegringsingan) he is the one who has the right to become the village apparatus, starting from the lowest level, namely Krama desa to become Luanan. In the assignment and function of the organizational structure of the muhu-muhu 
ceremony, in the process there is a medimedian tradition, in the initiator of the implementation of religion, starting from the top position in the organizational structure in the muhu-muhu ceremony, Kelian Gumi, Kelian Gumi is functional in its role towards the implementation of the Muhu-muhu ceremony which in its part is the medimedian tradition, namely as an advisory body.

Luanan, in meaningful meaning of the word is the elder or is a former Kelihan desa adat (bahan duluan), whose entire family members are still complete, namely still having wife and unmarried children. Functionally, Luanan is an executive body that serves as a preceptor, or provides guidance on how to process ceremonies in muhu-muhu along with the medi-median tradition. Kelihan desa or bahan duluan, as a leaders in the muhu-muhu ceremony procession and the medi-median tradition that will be held.

Bahan tebenan is a supervisory body for the completeness of facilities and infrastructure in the medi-median tradition along with the muhu-muhu ceremony in its specifications regarding facility ies and infrastructure related to the form of processed meats to be offered. Tambalapu duluan was a member of the initiator of the muhu-muhu ceremony along with the medimedian tradition held in Tenganan Pegringsingan, functionally tambalapu duluan was tasked with preparing supporting facilities and infrastructure from the muhumuhu and medi-median ceremonies. tambalapu tebenan in Bali terms can be said as a guardian, or a servant of the tasks carried out by tambalapu duluan. Pengeluduan in its position is the initiator of the implementation of the medi-median tradition and the muhu-muhu ceremony which is carried out in the form of a servant (pengayah), the last initiator in carrying out the muhu-muhu ceremony in which there is the medi-median tradition of Nandes. Nandes in their functional assignments in the implementation of the muhu-muhu and medimedian ceremonies, namely as pengayah desa or in general can be said as general assistants.

The process of internalization towards teruna-daha in the medi-median tradition that is associated with the development of students, there are three stages that represent the process or stage of internalization, namely: 1). Value Transformation Stage: This stage is a process carried out by the supervisor terunadaha in informing good and bad values. At this stage there is only verbal communication between the mentor and students or teruna-daha. 2). Transaction Value Phase: A stage of value education by carrying out two-way communication, or interaction between teruna-daha and supervisors who are reciprocal interactions. 3). Transinternalalization Stage: This stage is far more profound than the transaction phase. At this stage it is not only done with verbal communication but also mental attitude and personality. So at this stage, personality communication plays an active role between mentors and teruna-daha.

The medi-median tradition in the process of value internalization of terunadaha people in the traditional village of Tenganan Pegringsingan results in moral values that make individuals character. The results of the process of internalizing the character values of teruna-daha in the medimedian tradition are including: religious values, social values, tolerance values, disciplinary values, friendly/communicative values, creative values, aesthetic values and values of responsibility.

The medi-median tradition provides space for teruna-daha to understand tolerance to live side by side, internalization of the character values obtained by terunadaha, namely in the informal education system, even in the informal sphere, internalization of values interpreted in the medi-median tradition by teruna-daha, namely how to be as an individual can use himself to be useful for the lives of other individuals. medi-median symbols require careful and good planning, therefore a person is not only required to get the symbol, 
but is also required to prioritize the various values that exist in the medi-median making process, as well as bring some other elements such as elements aesthetics and philosophical elements, shape the character of a quality Teruna-daha through the internalization of the value of character education in the implementation of the Medi-median Tradition.

\section{Conclusion}

The conclusion is a description of the main contents of the discussion of the problem. Research conducted by researchers in the traditional village of Tenganan Pegringsingan by researching "Internalization Values of Character Education Towards The Teruna-Daha In The Medi-Median Tradition In Tenganan Pegringsingan Traditional Village Manggis District Karangasem District". so that researchers can conclude the results of the study as follows:

1. Medi-median tradition is the meaning of ritual about a sense of mutual respect between the lives of living things both on a scale and non-sense basis, the ritual / religious clad tradition has a function to balance the life carried out by the people of Tenganan Pegringsingan Indigenous Village who prioritize a life balance . The Medi-Median tradition "which was carried out was part of the MuhuMuhu ritual ritual which was held at sasih kapitu hud pang solas, adjusted to the calendar in Tenganan Pegringsingan Traditional Village. The initial process of the medimedian tradition, that is, the commencement of Masanggah juтmu is held when in sasih kaenam hud pang solas, Masanggah tengah is being carried out on kajengkliwon, sasih kapitu tanggal pang solas, Masanggah Duri is held right at the muhu-muhu ceremony which is mediated by the medi-median tradition, sasih kapitu hud pang solas. The muhu-muhu ceremony was carried out in two different places but remained in the area of Desa Adat Tenganan Pegringsingan, namely muhu-muhu devoted to Dalem Kangin/Pengemitan with the offering of godel bulu miik and Medi-Median Traditions carried out in the north to south region, with offering kucit butuan selem, regarding the time is right during the day. The organizational structure of the Tenganan Pegringsingan Traditional Village has an initiator in the implementation of medi-median tradition, namely Kelihan Gumi Completeness 6 people, Luanan 5 people, 1 Ungguan Luanan, 6 Bahan Duluan (Kelihan Desa), 6 Bahan Tebenan, 6 people Tambalapu Duluan, Tambalapu Tebenan 6 people, Pengeluduan and 1 Nandes.

2. The process of internalization of young people in the medi-median tradition that is associated with the development of students, there are three stages that represent the process or stage of the internalization, namely:

a. Value Transformation Stage: At this stage there is only verbal communication between the mentor and the students or Teruna-daha.

b. Transaction Phase Value: A two-way communication phase, or interaction between Teruna-daha and supervisors who are reciprocal interactions.

c. Transinternalisation Stage: This stage of personality communication plays an active role between counselors and Teruna-daha.

3. The process of value internalization of teruna-daha in the traditional village of Tenganan Pegringsingan, resulting in moral values that make individuals character. The results of the process of internalizing the character values of the teruna-daha in the medi-median tradition are: religious values, social values, tolerance values, disciplinary 
values, friendly/communicative values, creative values, aesthetic values and values of responsibility.

\section{References}

Arikunto, S.2000. Prosedur Penelitian,: Suatu Pendekatan Praktis, Yogyakarta : Rineka Cipta.

Hasbullah, 2009. Dasar-Dasar Ilmu Pendidikan. Jakarta : PT.Raja Grafindo Persada Mantra, Ida Bagus. 1993/1994. Tata Susila Agama Hindu Dharma Denpasar : Parisada Hindu Dharma Pusat.

Moleong, Lexy.J. 2013. Metedologi Penelitian Kualitatif Edisi Revisi. Bandung: Remaja Rosdakarya.

Nyoman, Ida Bagus Adi Putra Manuaba, 2011. Tradisi Ritual Materuna Nyoman Di Desa Adat Tenganan Pegringsingan Kecamatan Manggis Kabupaten Karangasem. Skripsi
STKIP Amplapurar Tidak diterbitkkan.

Parisada Hindu Dharma Indonesia Pusat, 2000. Seminar Kesatuan Tafsir Terhadap Aspek-aspek Agama Hindu.PHDI-XV.

Sabda Jayendra, Putu.2007. Tradisi Nyakan di Lebuh pada Perayaan Ngembak Geni di Desa Pakraman Munduk, Kecamatan Banjar, Kabupaten Buleleng (Perspektif Pendidikan Agama Hindu). Skripsi IHDN Denpasar. Tidak diterbitkan.

Sandika, I Ketut.2014. Membentuk Siswa Berkarakter Mulia melalui Pola Pembelajaran Pendidikan Agama Hindu.Surabaya: Paramita

Tim Penyusun. 2003. Undang-Undang Nomor 20 Tahun 2003 Tentang Sistem Pendidikan Nasional. Jakarta : Departemen Pendidikan Nasional Indonesia. 